\title{
MODELLING RELATIONSHIPS BETWEEN AGILITY, LEAN, RESILIENT, GREEN PRACTICES IN COLD SUPPLY CHAINS USING ISM APPROACH
}

\author{
Abbas AL-REFAIE (iD) ${ }^{1}$, Mohammad AL-TAHAT ${ }^{(D)}$, Natalija LEPKOVA (D) 2* \\ ${ }^{1}$ Department of Industrial Engineering, University of Jordan, Amman, Jordan \\ ${ }^{2}$ Department of Construction Management and Real Estate, \\ Vilnius Gediminas Technical University, Vilnius, Lithuania
}

Received 25 August 2019; accepted 05 April 2020

\begin{abstract}
This study aims at identifying the key agile, lean, resilient and green practices that influence capability of cold supply chain (CSC) using Interpretive Structural Modelling (ISM) technique. Various measures of lean, green, resilient, and agile practices in CSC were identified from previous studies and experts' opinions. Contextual relationships between practice measures were established via brainstorming session. Measures were then classified based on their driving and dependence powers. The results showed that measures of lean, green, resilient, and agile practices in CSC can be organized in a six-level structural model. Moreover, highly dependent measures at top level in CSC model are operational costs and customer satisfaction, whereas the highly driving at most bottom level of this model are ISO 14001 implementation and government support system for green cold supply chain. Validity of CSC model was assessed in three CSC firms; food, pharmaceutical, and Third Party logistics firms. In conclusion, measures emerging with higher driving power and those with high dependence in ISM hierarchy contribute significantly to enhancing capability of CSC. The proposed ISM may support decision makers in prioritization improvement efforts and achieving effective CSC.
\end{abstract}

Keywords: lean, green, resilient, agile, cold supply chain, interpretive structural modelling.

JEL Classification: L25, M11.

\section{Introduction}

In the today's changing global economy, cold supply chain (CSC) has become increasingly important due to the huge increasing demand for products of the temperature controlled industries; especially fresh agricultural products, manufactured food, chemicals, military services, and medical vaccines (Bogataj et al., 2005). The CSC is defined as a logistic system that provides a series of facilities for providing a temperature and humidity monitoring and

\footnotetext{
${ }^{\star}$ Corresponding author. E-mail: natalija.lepkova@vgtu.lt
}

\section{(C) 2020 The Author(s). Published by VGTU Press}

This is an Open Access article distributed under the terms of the Creative Commons Attribution License (http://creativecommons. org/licenses/by/4.0/), which permits unrestricted use, distribution, and reproduction in any medium, provided the original author and source are credited. 
control environment that maintains a product in an ideal condition throughout the supply chain stages and entities (Taylor, 2006). Nowadays, CSC firms are urged to apply new abilities to increase customer service and responsiveness, improve communication, reduce product development time, reduce duplication of inter-organizational processes, and minimize inventory in CSC network (Chien \& Shih, 2007; Blanchard, 2007). The implementation of agile, lean, resilient, and green practices can help firms in dealing with such challenges.

Agility was introduced as a rapid response to cover changes in demand for both volume and variety while maintaining the same customer service levels, liquidity, and cost structures (Cabral et al., 2015). The two concepts inherent in an agile firm are speed and flexibility. Agile cold supply chain (ACSC) is defined as the ability of CSC to respond quickly and adequately to short-term changes in demand, supply or the environment. ACSC is derived from the flexibility, responsiveness and effectiveness of the CSC (Bicocchi et al., 2019).

Further, the lean cold supply chain (LCSC) was introduced as a set of firms directly linked by upstream and downstream flows of products, services, finances, and information that collaboratively work to reduce cost and waste by efficiently and effectively pulling what is required to meet customer needs (Kumar et al., 2013). LCSC aims to minimizing inventories in the CSC, minimizing the amount of warehousing space required to store inventories, optimizing shipments to reduce the cost of moving inventory, and establishing long-term, stable supply contracts with the lowest negotiated cost. These goals make LCSC extremely a cost-efficient program (Holweg, 2007). As a result, LCSC network is empowered to execute superlative, unique customer-winning value at the lowest cost through the collaborative, real-time synchronization of product/service transfer, demand priorities, vital marketplace information, and logistics delivery capabilities. Lean supply chain management is then a systematic approach to enhance value to the customer by identifying and then eliminating waste through continuous improvement in pursuit of perfection.

Further, resilience is the ability of a global supply chain to reorganize and deliver its core functions continually, despite the impact of external and or internal shocks to the system. Resilient cold supply chain (RCSC) is characterized by four pillars; visibility, flexibility, collaboration, and control supported by a clearly defined governance structure and key enablers including people, process, and technology. In practice, firms can develop resilience in three main ways: increasing redundancy, building flexibility, and changing the corporate culture (Behzadi et al., 2017). However, SC operations can pose a significant threat to the environment in terms of carbon monoxide emissions, discarded packaging materials, scrapped toxic materials, traffic congestion and other forms of industrial pollution (Zhu et al., 2008).

Furthermore, green cold supply chain (GCSC) was introduced as an environmental innovation to minimize or eliminate wastages during product life cycle (Tang, 2006). As such, GCSC plays a vital role in influencing the total environment impact of any firm involved in CSC activities and thus contributing to sustainability performance enhancement. Companies that implement GSCM practices may benefit from cost savings (conserving materials, reduced energy, and water use), better public image, and decreased environmental liability (Gao et al., 2018). Further, lean supply chain management was analyzed by different authors from different perspectives, including concept of sustainability (Martínez-Jurado \& Moyano-Fuentes, 2014; Taghikhah et al., 2019). Ehsan et al. (2016) analyzed the effect of green practices on environmental performance and competitive advantage of cement supply chain. 
Nowadays, CSC firms are struggling to find new practices to enhance their competitive strengths. Recently, the influences of green, lean, resilient, and agile practices on the performance of traditional supply chain have been extensively covered in previous works (Espadinha-Cruz et al., 2012; Azevedo et al., 2016; Ruiz-Benitez et al., 2017). For example, Mejjaouli and Babiceanu (2018) proposed the logistics decision models associated with CSC of perishable products. The decision-making is performed in the cloud by temporary virtual machines associated with every shipment or series of shipments. Raut et al. (2019) proposed a fuzzy multi-criteria decision making approach for reducing food losses through evaluation and selection process for cold-third party logistics providers.

However, the influence of green, lean, resilient, and agile practices on the capability of CSC has rarely been examined. Interpretive structural modeling (ISM) approach is a graphtheoretic method that belongs to the causal mapping family of approaches (Sage, 1977). ISM is used for identifying and summarizing relationships among specific measures, which define a problem or an issue. This study, therefore, aims to develop an ISM model to depict the relationships between the lean, green, resilient, and agile practices on the capability of CSC, obtain valuable information on whether and how the measures of these practices are interrelated in the form of hierarchy using ISM, and rank them based on driving and dependent power. Further, this research develops items (questions) to assess the adoption effectiveness of CSC measures in three different industries. The remaining of this research is outlines in the following sequence. Section 1 presents the measures of agile, lean, resilient, green practices in CSC. Section 2 develops an ISM for CSC and then summarize research results. Section 3 discusses the ISM in three CSC cases. Conclusions are summarized in last Section.

\section{Measures of cold supply chain}

Various measures of the lean, agile, green and resilient practices in CSC were identified utilizing previous studies and are presented as follows.

\subsection{Measures of cold supply chain (CSC)}

Six measures of CSC are considered in this research (Bogataj et al., 2005; Paauwe, 2009; Svensson, 2010; Bicocchi et al., 2019). These measures are: (1) Information Technology (IT) adoption, which supports collaborative CSC processes and enhance its performance during various stages of product life cycle. The IT tools include: (i) Enterprise resource planning (ERP), which ensures quicker response to customer requirement, reduction in inventory costs, improvement in service levels, and reduction in logistics cost; (ii) Bar coding, which provides ease in identification of inventory items during storage, retrieval, pickup, inspection and dispatch, reduces paper work and processing time leading, minimizes human error, and thereby increases logistics system productivity through speed, accuracy and reliability; and (iii) Global positioning system, which supports real-time, three-dimensional positioning, and navigation all year around and all over the world. For example, GPS can be used as a tool of the traceability system in shipping processes in the CSC and combination with IoT technologies and other components of cyber-physical systems enable measurement of the expected customer shelf life at the arrival of products in any time of transportation (Bogataj 
et al., 2017), (2) Technology advancement adoption, which is mainly the advancement of machinery, equipment and software to improve the products and quality of processes. These new high complicated technologies require availability of the qualified and skilled staff to run and integrate them with the existing technologies, (3) Human Resource Management (HRM), which focuses on employee empowerment through alignment, authority, capability, and commitment, and aims to establish a more open, flexible and caring management style that enables staff work at their best to support a firm's mission. Typically, effective HRM helps firms implement effective CSC management, generate new ideas, adopt new technologies easily, and share knowledge with partners, (4) Operational Cost (OC), which is the cost in the whole CSC from raw material stage until the finished product is delivered to the customer. Usually, high OC generates heavy pressure on CSC as compared to conventional SC as the initial investment requirement by cold methodologies are too high, (5) Maintenance management strategies are mainly divided into preventive maintenance and corrective maintenance. Preventive maintenance is maintenance that is regularly performed on equipment to lessen the likelihood of failure, and maintain and/or extend the operational life so that it does not break down unexpectedly. However, corrective maintenance focuses on restoring equipment to its normal operating condition after it has broken. This approach can be a legitimate asset management strategy if resultant equipment failure will not do any harm or disrupt production significantly while it is repaired or replaced, and (6) Cold warehousing management system, which mainly controls the storage and movement of materials within a warehouse under controllable temperature and processes the receiving, shipping, picking, and putting away transactions. In practice, saving products under controllable temperature, sufficient warehouse space, and storing hazardous products separately are important requirements of cold warehousing.

\subsection{Measures of Green cold supply chain (GCSC)}

Four measures were identified for measuring of green practices in CSC (Hsu \& $\mathrm{Hu}, 2008$; Khidir et al., 2010; Luthra et al., 2011): (1) the organizational awareness for GCSC, which is a level of understanding different aspects of the firm, including workings, structure, and culture. $\mathrm{OW}$ is the most important factor in managing proactive change in firm that helps to improve staffing decisions, team building, communication, culture, leadership effectiveness, and, as a result, increase revenue and profitability by establishing competitive advantage and creating consistent results, (2) government support system for green supply chain (GSS); because governmental bodies are the most obvious external stakeholders when it comes to environmental issues. GSS can influence GCSC initiatives by offering a capital rebate for purchasing environmental products, by indirect encouragement/discouragement via varying tax rates, or by encouragement/discouragement the adoption of innovation. Time-consuming regulatory requirements, fees or tax structures s may discourage adoption of GCSC. Thus, government should develop friendly policies and offer special benefits to those CSC firms in implementing GP, facilitate the exportation of GSC products, and reduce taxes for firms that apply GCSC, (3) implementation of green practices (GP), which are those practices that can lead to more environmentally friendly and ecologically responsible decisions and lifestyles. An important aspect of GP is the green distribution, which consists of green packaging and 
green logistics. Packaging characteristics; such as, size, shape, and materials have an impact on distribution because of their effect on the transport characteristics of the product. Better packaging, along with rearranged loading patterns can reduce materials usage, increases space utilization in the warehouse and in the trailer, and reduce the amount of handling required, and (4) implementation of ISO 14001, which is the world most recognized standard to manage better the impact of CSC activities on the environment and to demonstrate sound environmental management. In GCSC context, ISO 14001 implementation can act indirectly to influence all partners to adopt more environmentally friendly practices, promotes the reduction in resource usage and waste reduction, and contributes to quality improvement.

\subsection{Agile cold supply chain (ACSC) measures}

The ACSC involves two measures (Carvalho et al., 2011; Cabral et al., 2015; Balaji et al., 2016): (1) Agility and responsiveness to unpredictable demand, which imply that ACSC is able to handle unpredictability- and a constant stream of new, innovative products- with speed and flexibility and adapt to unanticipated external economic changes; such as, economic swings, changes in technology, or changes to customer demand. Implementing ACSC allows firms to quickly adjust their sourcing, logistics, and sales, and (2) customer satisfaction, which is the degree to which customers along the ACSC are satisfied with the product and/or service received.

\subsection{Resilient cold supply chain (RCSC) measures}

Two RCSC measures were identified (Iakovou et al., 2007; Zobel, 2011; Carvalho et al., 2012; Govindan et al., 2015): (1) Preparedness to incidents, which is the systematic identification, analyzing and correction for any possible hazards that may or not produce human loses to prevent a future re-occurrence of it. Incident management is defined as the capability to effectively manage unexpected disruptive events with the objective of minimizing impacts and maintaining or restoring normal operations within defined time limits. A viable incident management capability requires the allocation of human and material resources to support business operations to assure continuity of the minimum of enterprise operations and contain security breaches in accordance with the enterprise risk strategy. A written plan for incident management is a key for success for preparedness process, and (2) Updated information; for example, up-to-date information about products, customers, staff and their functions, supplier's information, continuous location and time information of logistics, and delivery of products, play an important role in contemporary RCSC and must be stored, managed, and processed.

\subsection{Lean cold supply chain (LCSC) measures}

Lean paradigm strives to identify and eliminate all non-add value activities, or waste, involved in any kind of business process. The concept of lean production was extended to minimize waste in the downstream or distribution supply chain while making the right product available to the end customer at the right time and location. The common lean manufacturing tools are 5S and KAIZEN (Kumar et al., 2013; Govindan et al., 2015; Cabral et al., 2015). The 
$5 S$ is the methodology of creation and maintaining well-organized, clean, high effective and high quality workplace. It results in the effective organization of the workplace, elimination of losses connected with failures and breaks, improvement of work quality and safety. Further, the KAIZEN management is dedicated to the improvement of productivity, efficiency, quality and, in general, of business excellence. The Kaizen methods are internationally acknowledged as tools of continual improvement, through small steps, of the economical results of firms.

\section{Application of ISM approach}

The methodology for developing the ISM for CSC is outlined in the steps shown in Figure 1.

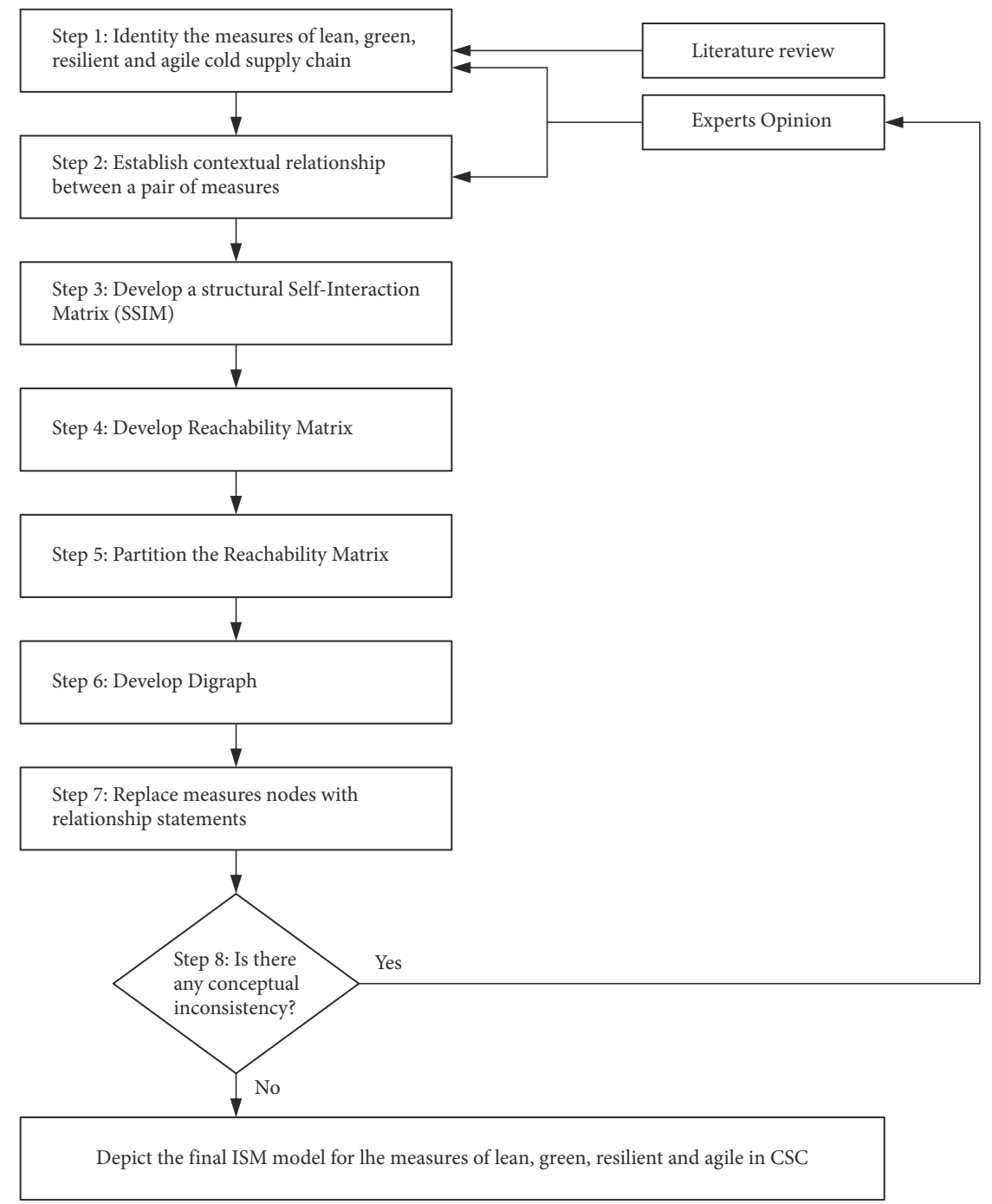

Figure 1. Flow diagram for preparing the ISM model 


\subsection{Structural self-interaction matrix (SSIM) and reachability matrix}

A total of ten academics and professionals, who have recent involvement lean, agile, green, resilient practices in CSC and a sound knowledge and understanding on CSC management, participated in developing the structural Self-Interaction Matrix (SSIM). The academics and professionals were assigned equal weights. Contextual relationships were then identified by carrying out brainstorming session to determine the measures of CSC, GCSC, ACSC, RCSC, and LCSC along with the SSIM as shown in Table 1.

In the SSIM, four symbols are used to denote the direction of relationship between any pair of measures; $i$ and $j$, as follows: $\mathrm{V}$ : Measure $i$ will lead to measure $j$; A: Measure $j$ will lead to measure $i$; X: Measures $i$ and $j$ will lead to each other; O: Measures $i$ and $j$ are unrelated. The reachability matrix is then developed from SSIM. The SSIM will be then converted in to a binary matrix; named Initial Reachability Matrix, by transforming the information of each cell of SSIM (V, A, X, O) into binary digits (i.e., ones or zeros) in the initial reachability matrix:

- If cell $(i, j)$ in the SSIM is V, then cell $(i, j)$ value in the reachability matrix will be 1 and cell $(j, i)$ value will be 0 ; for example, symbol in cell $(1,15)$ is $V$, thus ' 1 ' is set in cell $(1,15)$ and ' 0 ' in cell $(15,1)$.

- If cell $(i, j)$ in the SSIM is A, then cell $(i, j)$ value in the reachability matrix will be 0 and cell $(i, j)$ value will be 1 ; for example, the symbol in cell $(4,5)$ is $A$, therefore the value of cell $(4,5)$ is ' 0 ' and cell $(5,4)$ value is ' 1 '.

- If cell $(i, j)$ in the SSIM is X, then cell $(i, j)$ value in the reachability matrix will be ' 1 ' and cell $(j, i)$ value will also be 1 ; for example, symbol in cell $(6,8)$ is $\mathrm{X}$, therefore, both values of cells $(6,8)$ and $(8,6)$ are ' 1 '.

- If cell $(i, j)$ value in the SSIM is $\mathrm{O}$, cell $(i, j)$ value in the reachability matrix will be ' 0 ' and cell $(j, i)$ value will also be " 0 "; for example, the symbol in cells $(13,14)$ and $(14$, 13 ) is $\mathrm{O}$, thus both values are set ' 0 '.

By applying these rules, an initial reachability matrix for the measures of lean, green, resilient and agile in CSC were obtained as shown in Table 2. For example, measures $(1,2,3,4,5,6,8,9,10,11,12,14)$ affect measure 15 , which affects measures $(3,7,9,12,13)$. Consequently, there are indirect relationships between $(1,3),(1,7),(1,9),(1,12),(1,13),(2,3),(2,7)$, $(2,9),(2,12),(2,13),(3,3),(3,7),(3,9),(3,12),(3,13),(4,3),(4,7),(4,9),(4,12),(4,13),(5,3)$, $(5,7),(5,9),(5,12),(5,13),(6,3),(6,7),(6,9),(6,12),(6,13),(8,3),(8,7),(8,9),(8,12),(8,13)$, (9,3), (9,7), (9,9), (9,12), (9,13), (10,3), (10,7), (10,9), (10,12), (10,13), (11,3), (11,7), (11,9), $(11,12),(11,13),(12,3),(12,7),(12,9),(12,12),(12,13),(14,3),(14,7),(14,9),(14,12),(14,13)$. The driving power and the dependence power of each measure were calculated and then listed in the Table 3.

The reachability and antecedent set for each measure were determined from the final reachability matrix shown in Table 3 . The reachability set for a measure consists of the measure itself and the other measures it influences. The antecedent set consists of the measure itself and other measures which may influence it. Reachability and Antecedent set and Intersection sets were found for the all measures. The measure having same reachability set and the intersection set was assigned as top level measure in the ISM hierarchy; or level 1. After 
deciding level 1 measures, those measures were then discarded for finding further Levels. The iterative procedure was continued until Level of each measure was found. Six levels were identified as shown in Table 4; where operation costs (No. 7) and customer satisfaction (No. 13) are the top level measures, whereas government support system for GCSC (No. 5) and ISO 14001 implementation (No. 8) are found as the most important bottom level measures. Table 5 summarizes the measures of lean, green, resilient and agile practices in CSC with their assigned ISM levels. Utilizing Table 5, the complete ISM was finally constructed and then depicted in Figure 2.

Table 1. Structured Self Intersection Matrix (SSIM) for CSC

\begin{tabular}{|c|c|c|c|c|c|c|c|c|c|c|c|c|c|c|c|c|}
\hline Measure & Practice & 15 & 14 & 13 & 12 & 11 & 10 & 9 & 8 & 7 & 6 & 5 & 4 & 3 & 2 & 1 \\
\hline IT implementation & Cold & $\mathrm{V}$ & $\mathrm{X}$ & $\mathrm{V}$ & $\mathrm{V}$ & $\mathrm{V}$ & $\mathrm{V}$ & $\mathrm{V}$ & $\mathrm{A}$ & $\mathrm{V}$ & $\mathrm{V}$ & $\mathrm{O}$ & A & $\mathrm{V}$ & $\mathrm{V}$ & \\
\hline $\begin{array}{l}\text { 2. Technology } \\
\text { advancement adoption }\end{array}$ & Cold & $\mathrm{V}$ & V & $\mathrm{O}$ & $\mathrm{V}$ & V & V & V & $\mathrm{A}$ & V & $\mathrm{V}$ & $\mathrm{O}$ & $\mathrm{A}$ & V & & \\
\hline $\begin{array}{l}\text { 3. Human resources } \\
\text { management }\end{array}$ & Cold & $\mathrm{X}$ & $\mathrm{X}$ & V & $\mathrm{X}$ & V & V & V & V & V & $\mathrm{X}$ & $\mathrm{O}$ & $\mathrm{O}$ & & & \\
\hline $\begin{array}{l}\text { 4. Organizational } \\
\text { awareness for GCSC }\end{array}$ & Green & $\mathrm{V}$ & V & V & $\mathrm{O}$ & V & V & $\mathrm{O}$ & $\mathrm{X}$ & V & $\mathrm{X}$ & A & & & & \\
\hline $\begin{array}{l}\text { 5. Government support } \\
\text { system for GCSC }\end{array}$ & Green & $\mathrm{V}$ & $\mathrm{O}$ & $\mathrm{V}$ & $\mathrm{O}$ & $\mathrm{O}$ & $\mathrm{O}$ & $\mathrm{O}$ & $\mathrm{O}$ & $\mathrm{O}$ & V & & & & & \\
\hline $\begin{array}{l}\text { 6. Implementing green } \\
\text { practices }\end{array}$ & Green & V & A & $\mathrm{V}$ & $\mathrm{O}$ & A & $\mathrm{O}$ & $\mathrm{O}$ & $\mathrm{X}$ & V & & & & & & \\
\hline 7. Operational costs & Cold & A & A & $\mathrm{O}$ & A & A & A & A & $\mathrm{O}$ & & & & & & & \\
\hline $\begin{array}{l}\text { 8. ISO } 14001 \\
\text { implementation }\end{array}$ & Green & V & $\mathrm{V}$ & $\mathrm{V}$ & $\mathrm{O}$ & $\mathrm{O}$ & V & V & & & & & & & & \\
\hline $\begin{array}{l}\text { 9. Lean supply chain and } \\
\text { value addition }\end{array}$ & Lean & $\mathrm{X}$ & A & $\mathrm{V}$ & $\mathrm{X}$ & A & A & & & & & & & & & \\
\hline $\begin{array}{l}\text { 10. Preparedness to } \\
\text { incidents and emergences }\end{array}$ & Resilient & $\mathrm{V}$ & A & $\mathrm{O}$ & $\mathrm{O}$ & $\mathrm{A}$ & & & & & & & & & & \\
\hline 11. Updating information & Resilient & $\mathrm{V}$ & A & $\mathrm{V}$ & $\mathrm{V}$ & & & & & & & & & & & \\
\hline $\begin{array}{l}\text { 12. Agility and } \\
\text { responsiveness to } \\
\text { unpredictable demand }\end{array}$ & Agile & $\mathrm{X}$ & A & V & & & & & & & & & & & & \\
\hline 13. Customer satisfaction & Agile & A & $\mathrm{O}$ & & & & & & & & & & & & & \\
\hline $\begin{array}{l}\text { 14. Maintenance } \\
\text { Management }\end{array}$ & Cold & V & & & & & & & & & & & & & & \\
\hline $\begin{array}{l}\text { 15. Cold warehousing and } \\
\text { Inventory management }\end{array}$ & Cold & & & & & & & & & & & & & & & \\
\hline
\end{tabular}


Table 2. Initial reachability matrices

\begin{tabular}{|l|c|c|c|c|c|c|c|c|c|c|c|c|c|c|c|}
\hline \multicolumn{10}{|c|}{ Initial reachability matrix } \\
\hline \multicolumn{1}{|c|}{ Measure } & 1 & 2 & 3 & 4 & 5 & 6 & 7 & 8 & 9 & 10 & 11 & 12 & 13 & 14 & 15 \\
\hline 1. IT implementation & 1 & 1 & 1 & 0 & 0 & 1 & 1 & 0 & 1 & 1 & 1 & 1 & 1 & 1 & 1 \\
\hline 2. Technology advancement adoption & 0 & 1 & 1 & 0 & 0 & 1 & 1 & 0 & 1 & 1 & 1 & 1 & 0 & 1 & 1 \\
\hline 3. Human resources management & 0 & 0 & 1 & 0 & 0 & 1 & 1 & 1 & 1 & 1 & 1 & 1 & 1 & 1 & 1 \\
\hline 4. Organizational awareness for GCSC & 1 & 1 & 0 & 1 & 0 & 1 & 1 & 1 & 0 & 1 & 1 & 0 & 1 & 1 & 1 \\
\hline $\begin{array}{l}\text { 5. Government support system for } \\
\text { GCSC }\end{array}$ & 0 & 0 & 0 & 1 & 1 & 1 & 0 & 0 & 0 & 0 & 0 & 0 & 1 & 0 & 1 \\
\hline 6. Implementing green practices & 0 & 0 & 1 & 1 & 0 & 1 & 1 & 1 & 0 & 0 & 0 & 0 & 1 & 0 & 1 \\
\hline 7. Operational costs & 0 & 0 & 0 & 0 & 0 & 0 & 1 & 0 & 0 & 0 & 0 & 0 & 0 & 0 & 0 \\
\hline 8. ISO 14001 implementation & 1 & 1 & 0 & 1 & 0 & 1 & 0 & 1 & 1 & 1 & 0 & 0 & 1 & 1 & 1 \\
\hline $\begin{array}{l}\text { 9. Lean supply chain and value } \\
\text { addition }\end{array}$ & 0 & 0 & 0 & 0 & 0 & 0 & 1 & 0 & 1 & 0 & 0 & 1 & 1 & 0 & 1 \\
\hline $\begin{array}{l}\text { 10. Preparedness to incidents and } \\
\text { emergences }\end{array}$ & 0 & 0 & 0 & 0 & 0 & 0 & 1 & 0 & 1 & 1 & 0 & 0 & 0 & 0 & 1 \\
\hline 11. Updating information & 0 & 0 & 0 & 0 & 0 & 1 & 1 & 0 & 1 & 1 & 1 & 1 & 1 & 0 & 1 \\
\hline $\begin{array}{l}\text { 12. Agility and responsiveness to } \\
\text { unpredictable demand }\end{array}$ & 0 & 0 & 1 & 0 & 0 & 0 & 1 & 0 & 1 & 0 & 0 & 1 & 1 & 0 & 1 \\
\hline 13. Customer satisfaction & 0 & 0 & 0 & 0 & 0 & 0 & 0 & 0 & 0 & 0 & 0 & 0 & 1 & 0 & 0 \\
\hline 14. Maintenance Management & 1 & 0 & 1 & 0 & 0 & 1 & 1 & 0 & 1 & 1 & 1 & 1 & 0 & 1 & 1 \\
\hline $\begin{array}{l}\text { 15. Cold warehousing and Inventory } \\
\text { management }\end{array}$ & 0 & 0 & 1 & 0 & 0 & 0 & 1 & 0 & 1 & 0 & 0 & 1 & 1 & 0 & 1 \\
\hline
\end{tabular}

Table 3. final reachability matrices

\begin{tabular}{|c|c|c|c|c|c|c|c|c|c|c|c|c|c|c|c|c|c|}
\hline \multicolumn{17}{|c|}{ Final reachability matrix } & \multirow{2}{*}{\begin{tabular}{|c} 
Driver \\
13
\end{tabular}} \\
\hline 1. IT implementation & 1 & 1 & 1 & 1 & & & 1 & 1 & 0 & 1 & 1 & 1 & 1 & 1 & 1 & 1 & \\
\hline 2. Technology advancement adoption & 1 & 1 & 1 & 1 & & & 1 & 1 & 1 & 1 & 1 & 1 & 1 & 1 & 1 & 1 & 14 \\
\hline 3. Human resources management & 1 & 1 & 1 & 1 & & & 1 & 1 & 1 & 1 & 1 & 1 & 1 & 1 & 1 & 1 & 14 \\
\hline 4. Organizational awareness for GCSC & 1 & 1 & 1 & 1 & & & 1 & 1 & 1 & 1 & 1 & 1 & 1 & 1 & 1 & 1 & 14 \\
\hline 5. Government support system for GCSC & 0 & 0 & 1 & 1 & & & 1 & 1 & 0 & 1 & 0 & 0 & 1 & 1 & 0 & 1 & 9 \\
\hline 6. Implementing green practices & 0 & 1 & 1 & 1 & & & 1 & 1 & 1 & 1 & 0 & 0 & 1 & 1 & 0 & 1 & 10 \\
\hline 7. Operational costs & 0 & 0 & 0 & 0 & & & ) & 1 & 0 & 0 & 0 & 0 & 0 & 0 & 0 & 0 & 1 \\
\hline 8. ISO 14001 implementation & 1 & 1 & 1 & 1 & & & L & 1 & 1 & 1 & 1 & 1 & 1 & 1 & 1 & 1 & 14 \\
\hline 9. Lean supply chain and value addition & 0 & 0 & 1 & 0 & & & & 1 & 0 & 1 & 0 & 0 & 1 & 1 & 0 & 1 & 6 \\
\hline 10. Preparedness to incidents and emergences & 0 & 0 & 1 & 0 & & & 0 & 1 & 0 & 1 & 1 & 0 & 1 & 1 & 0 & 1 & 7 \\
\hline 11. Updating information & 0 & 0 & 1 & 0 & & & 1 & 1 & 0 & 1 & 1 & 1 & 1 & 1 & 1 & 1 & 10 \\
\hline $\begin{array}{l}\text { 12. Agility and responsiveness to } \\
\text { unpredictable demand }\end{array}$ & 0 & 0 & 1 & 0 & & & o & 1 & 0 & 1 & 0 & 0 & 1 & 1 & 0 & 1 & 6 \\
\hline 13. Customer satisfaction & 0 & 0 & 0 & 0 & & & j & 0 & 0 & 0 & 0 & 0 & 0 & 1 & 0 & 0 & 1 \\
\hline 14. Maintenance Management & 1 & 0 & 1 & 0 & & & 1 & 1 & 0 & 1 & 1 & 1 & 1 & 0 & 1 & 1 & 10 \\
\hline $\begin{array}{l}\text { 15. Cold warehousing and Inventory } \\
\text { management }\end{array}$ & 0 & 0 & 1 & 0 & & & & 1 & 0 & 1 & 0 & 0 & 1 & 1 & 0 & 1 & 6 \\
\hline Dependence & 6 & 6 & 13 & \begin{tabular}{l|l}
37 \\
\end{tabular} & & & & 14 & 5 & 13 & 8 & 7 & 13 & \begin{tabular}{|l|}
13 \\
\end{tabular} & \begin{tabular}{|l|l|}
7 & \\
\end{tabular} & 13 & 135 \\
\hline
\end{tabular}


Table 4. Partitioning of levels

\begin{tabular}{|c|c|c|c|c|c|}
\hline Iteration & Variable & Reachability Set & Antecedent Set & Intersection & Level \\
\hline \multirow{15}{*}{1} & 1 & $\begin{array}{l}1,2,3,4,6,7,9,10,11,12,13 \\
14,15\end{array}$ & $1,2,3,4,8,14$ & $1,2,3,4,14$ & \\
\hline & 2 & $\begin{array}{l}1,2,3,4,6,7,8,9,10,11,12,13 \\
14,15\end{array}$ & $1,2,3,4,6,8$ & $1,2,3,4,6,8$ & \\
\hline & 3 & $\begin{array}{l}1,2,3,4,6,7,8,9,10,11,12,13 \\
14,15\end{array}$ & $\begin{array}{l}1,2,3,4,5,6,8,9,10,11 \\
12,14,15\end{array}$ & $\begin{array}{l}1,2,3,4,6,8,9,10 \\
11,12,14,15\end{array}$ & \\
\hline & 4 & $\begin{array}{l}1,2,3,4,6,7,8,9,10,11,12,13 \\
14,15\end{array}$ & $1,2,3,4,5,6,8$ & $1,2,3,4,6,8$ & \\
\hline & 5 & $3,4,5,6,7,9,12,13,15$ & 5 & 5 & \\
\hline & 6 & $2,3,4,6,7,8,9,12,13,15$ & $1,2,3,4,5,6,8,11,14$ & $2,3,4,6,8$ & \\
\hline & 7 & 7 & $\begin{array}{l}1,2,3,4,5,6,7,8,9,10 \\
11,12,14,15\end{array}$ & 7 & I \\
\hline & 8 & $\begin{array}{l}1,2,3,4,6,7,8,9,10,11,12,13 \\
14,15\end{array}$ & $2,3,4,6,8$ & $2,3,4,6,8$ & \\
\hline & 9 & $3,7,9,12,13,15$ & $\begin{array}{l}1,2,3,4,5,6,8,9,10,11, \\
12,14,15\end{array}$ & $3,9,12,15$ & \\
\hline & 10 & $3,7,9,10,12,13,15$ & $1,2,3,4,8,10,11,14$ & 3,10 & \\
\hline & 11 & $3,6,7,9,10,11,12,13,14,15$ & $1,2,3,4,8,11,14$ & $3,11,14$ & \\
\hline & 12 & $3,7,9,12,13,15$ & $\begin{array}{l}1,2,3,4,5,6,8,9,10,11 \\
12,14,15\end{array}$ & $3,9,12,15$ & \\
\hline & 13 & 13 & $\begin{array}{l}1,2,3,4,5,6,8,9,10,11 \\
12,13,15\end{array}$ & 13 & I \\
\hline & 14 & $1,3,6,7,9,10,11,12,14,15$ & $1,2,3,4,8,11,14$ & $1,3,11,14$ & \\
\hline & 15 & $3,7,9,12,13,15$ & $\begin{array}{l}1,2,3,4,5,6,8,9,10,11 \\
12,14,15\end{array}$ & $3,9,12,15$ & \\
\hline \multirow{13}{*}{2} & 1 & $1,2,3,4,6,9,10,11,12,14,15$ & $1,2,3,4,8,14$ & $1,2,3,4,14$ & \\
\hline & 2 & $1,2,3,4,6,8,9,10,11,12,14,15$ & $1,2,3,4,6,8$ & $1,2,3,4,6,8$ & \\
\hline & 3 & $1,2,3,4,6,8,9,10,11,12,14,15$ & $\begin{array}{l}1,2,3,4,5,6,8,9,10,11 \\
12,14,15\end{array}$ & $\begin{array}{l}1,2,3,4,6,8,9,10 \\
11,12,14,15\end{array}$ & II \\
\hline & 4 & $\begin{array}{l}1,2,3,4,6,8,9,10,11,12,14 \\
15\end{array}$ & $1,2,3,4,5,6,8$ & $1,2,3,4,6,8$ & \\
\hline & 5 & $3,4,5,6,9,12,15$ & 5 & 5 & \\
\hline & 6 & $2,3,4,6,8,9,12,15$ & $1,2,3,4,5,6,8,11,14$ & $2,3,4,6,8$ & \\
\hline & 8 & $1,2,3,4,6,8,9,10,11,12,14,15$ & $2,3,4,6,8$ & $2,3,4,6,8$ & \\
\hline & 9 & $3,9,12,15$ & $\begin{array}{l}1,2,3,4,5,6,8,9,10,11 \\
12,14,15\end{array}$ & $3,9,12,15$ & II \\
\hline & 10 & $3,9,10,12,15$ & $1,2,3,4,8,10,11,14$ & 3,10 & \\
\hline & 11 & $3,6,9,10,11,12,14,15$ & $1,2,3,4,8,11,14$ & $3,11,14$ & \\
\hline & 12 & $3,9,12,15$ & $\begin{array}{l}1,2,3,4,5,6,8,9,10,11, \\
12,14,15\end{array}$ & $3,9,12,15$ & II \\
\hline & 14 & $1,3,6,9,10,11,12,14,15$ & $1,2,3,4,8,11,14$ & $1,3,11,14$ & \\
\hline & 15 & $3,9,12,15$ & $\begin{array}{l}1,2,3,4,5,6,8,9,10,11, \\
12,14,15\end{array}$ & $3,9,12,15$ & II \\
\hline
\end{tabular}


End of Table 4

\begin{tabular}{|c|c|c|c|c|c|}
\hline Iteration & Variable & Reachability Set & Antecedent Set & Intersection & Level \\
\hline \multirow{9}{*}{3} & 1 & $1,2,4,6,10,11,14$ & $1,2,4,8,14$ & $1,2,4,14$ & \\
\hline & 2 & $1,2,4,6,8,10,11,14$ & $1,2,4,6,8$ & $1,2,4,6,8$ & \\
\hline & 4 & $1,2,4,6,8,10,11,14$ & $1,2,4,5,6,8$ & $1,2,4,6,8$ & \\
\hline & 5 & $4,5,6$ & 5 & 5 & \\
\hline & 6 & $2,4,6,8$ & $1,2,4,5,6,8,11,14$ & $2,4,6,8$ & III \\
\hline & 8 & $1,2,4,6,8,10,11,14$ & $2,4,6,8$ & $2,4,6,8$ & \\
\hline & 10 & 10 & $1,2,4,8,10,11,14$ & 10 & III \\
\hline & 11 & $6,10,11,14$ & $1,2,4,8,11,14$ & 11,14 & \\
\hline & 14 & $1,6,10,11,14$ & $1,2,4,8,11,14$ & $1,11,14$ & \\
\hline \multirow{7}{*}{4} & 1 & $1,2,4,11,14$ & $1,2,4,8,14$ & $1,2,4,14$ & \\
\hline & 2 & $1,2,4,8,11,14$ & $1,2,4,8$ & $1,2,4,8$ & \\
\hline & 4 & $1,2,4,8,11,14$ & $1,2,4,5,8$ & $1,2,4,8$ & \\
\hline & 5 & 4,5 & 5 & 5 & \\
\hline & 8 & $1,2,4,8,11,14$ & $2,4,8$ & $2,4,8$ & \\
\hline & 11 & 11,14 & $1,2,4,8,11,14$ & 11,14 & $\mathrm{~V}$ \\
\hline & 14 & $1,11,14$ & $1,2,4,8,11,14$ & $1,11,14$ & $\mathrm{~V}$ \\
\hline \multirow{5}{*}{5} & 1 & $1,2,4$ & $1,2,4,8$ & $1,2,4$ & VI \\
\hline & 2 & $1,2,4,8$ & $1,2,4,8$ & $1,2,4,8$ & VI \\
\hline & 4 & $1,2,4,8$ & $1,2,4,5,8$ & $1,2,4,8$ & VI \\
\hline & 5 & 4,5 & 5 & 5 & \\
\hline & 8 & $1,2,4,8$ & $2,4,8$ & $2,4,8$ & \\
\hline \multirow{2}{*}{6} & 5 & 5 & 5 & 5 & VII \\
\hline & 8 & 4,8 & 4,8 & 4,8 & VII \\
\hline
\end{tabular}

Table 5. Summary of partitioning of levels

\begin{tabular}{|c|l|c|}
\hline Level & \multicolumn{1}{|c|}{ Measure } & No. \\
\hline \multirow{2}{*}{ 1st } & Operational costs & 7 \\
& Customer satisfaction & 13 \\
\hline \multirow{3}{*}{ 2nd } & Lean supply chain and value addition & 9 \\
& Human resources management & 3 \\
& Agility and responsiveness to unpredictable demand & 12 \\
& Cold warehousing and Inventory management & 15 \\
\hline \multirow{2}{*}{3 rd } & Implementing green practices & 6 \\
& Preparedness to incidents and emergences & 10 \\
\hline \multirow{2}{*}{ 4th } & Maintenance Management & 14 \\
& Updating information & 11 \\
\hline \multirow{2}{*}{ 5th } & IT implementation & 1 \\
& Technology advancement adoption & 2 \\
\cline { 2 - 3 } 6th & Organizational awareness for GCSC & 4 \\
\hline & ISO 14001 implementation & 8 \\
\hline
\end{tabular}




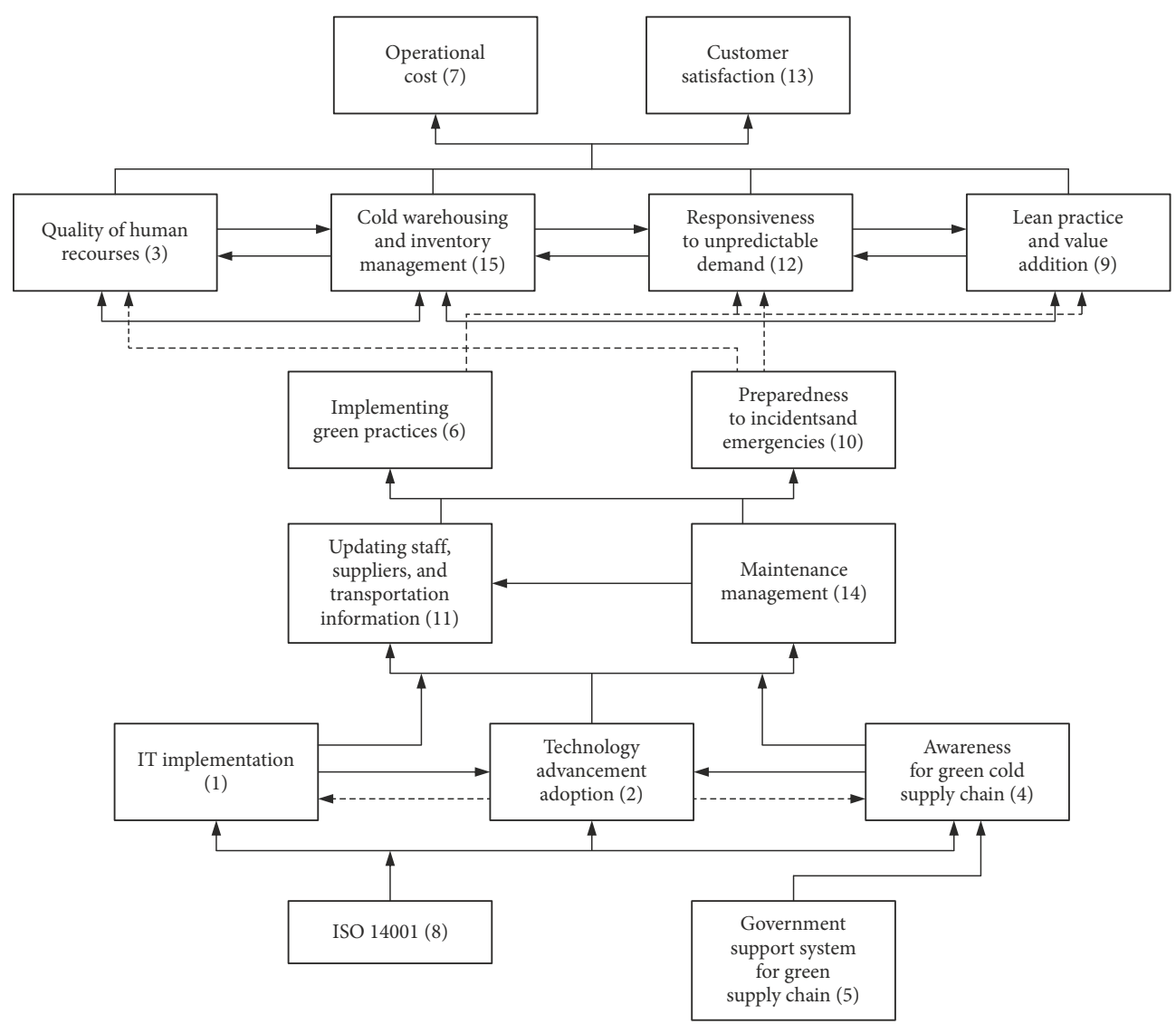

Figure 2. ISM Model for Measures to implement lean, green, resilient, and agile cold supply chain

\subsection{Classification of CSC measures}

The driving power and the dependency power of measures must be assessed. Higher dependence values for a measure means that a number of other measures have to be addressed before its removal, while high driving power of a measure means that a number of other measures could be removed by its removal. Measures are classified as shown in Figure 3 into nine clusters according to low, middle, and high dependence-driving power combinations. For example, autonomous measures (cluster I) are identified as low-low dependence-driving power combination, dependent measures (cluster VII) of high-low power combinations, linkage measures (cluster V) of middle-middle combination, and independent measures (III) of low-high dependence-driving power combination. From Figure 3, the following results are obtained:

- For low dependence power, no measures belong to low-low (cluster I), while one measure; government support system for GCSC (No. 5), has low-middle power com- 
bination in cluster (II) and one measure; ISO 14001 implementation, belongs to lowhigh power combination in cluster III. Consequently, government support and ISO 14001 implementation, which are both green capabilities of CSC are important to drive the improvement of green capability of CSC.

- For middle dependence power, no measures fall in middle-low power combination (cluster IV). The middle-middle power combination (cluster V) includes implementing green practices (Green, No. 6), preparedness to incidents and emergencies (Resilient, No. 10), maintenance management (Cold, No. 14), and updating staff, suppliers, and transportation information (Resilient, No. 11). Consequently, these measures are both driven by lower level measures and drive the progress of the green, resilient, and CSC capability. Finally, the middle-high power combination (cluster VI) contains IT implementation (Cold, No. 1), Technology advancement adoption (Cold, No. 2), and organizational awareness for green cold supply chain (Green, No. 4). Although these measures are dependent on measures in lower level, they have larger influences in driving cold and green the upper level measures in the CSC than their dependency effects.

- For high dependence power, the high-low power combination (cluster VII) consists of operational costs (Cold, No. 7) and customer satisfaction (Agile, No. 13). Consequently, these measures are most influenced by the measures in lower levels. Because of their high dependency and low driving powers, they are determined as the top level measures in the ISM model. Further, the high-middle power combination (cluster VIII) includes lean practices and value addition (Lean, No. 9), responsiveness to unpredictable demand (Agile, No. 12), and cold warehousing and inventory management (Cold, No. 15). These lean, agility, and cold measures have more dependency on lower level measures than driving upper level measures. Finally, the high-high power combination (cluster XI) includes human resources management (Cold, No. 3), which is both highly dependent on lower level measures and highly driving upper level measures in the CSC.

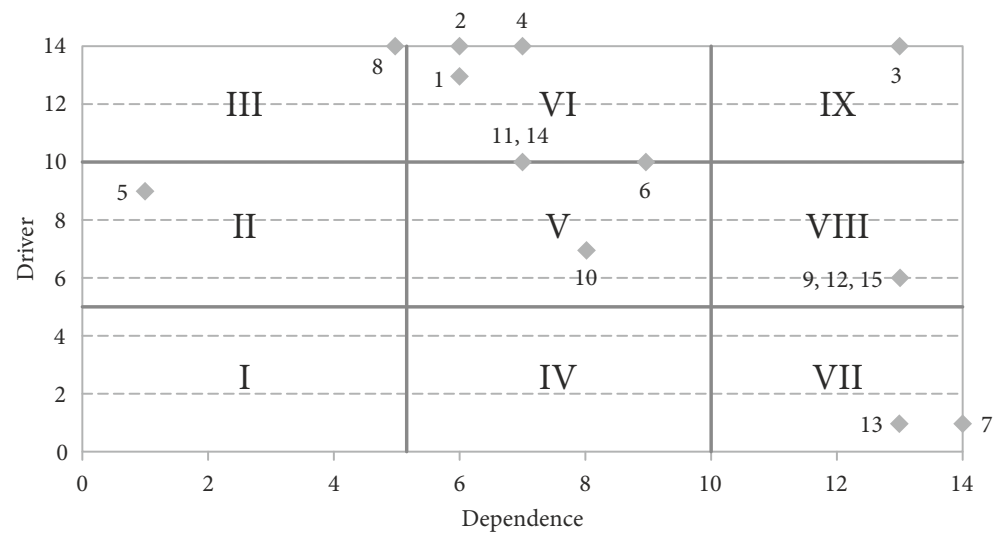

Figure 3. Classification of measures of CSC 


\section{CSC model implications}

A survey tool which includes measuring items (questions) of the ISM measures of CSC was prepared accurately as shown in Table 6. The ISM model was utilized to assess performance of CSC firms. The survey was edited by experts from both industry and academia. Firms from food industry, pharmaceutical industries, and third party logistics (3PL) were selected. Fifty surveys were sent by e-mail and in person. The surveys were completely filled by supply chain managers and engineers from logistics department with extensive experience in CSC processes. A Likert scale of a range from 1 to 5; Extremely agree: $>4$ to 5, agree: $>3$ to 4 , Fair: $>2$ to 3, disagree: $>1$ to 2 , and Extremely disagree: 1 , is used to assess respondent's average response about CSC measures. Table 6 displays the values of the calculated means and standard deviations in each firm for all measures.

Table 6. Survey items for CSC item measures

\begin{tabular}{|c|c|c|c|}
\hline \multicolumn{4}{|c|}{ CSC measures } \\
\hline No. & Item & No. & Item \\
\hline \multirow{5}{*}{1} & $\begin{array}{l}\text { - Application of an effective computerized } \\
\text { system }\end{array}$ & \multirow{5}{*}{14} & $\begin{array}{l}\text { - There is a maintenance department for } \\
\text { CS }\end{array}$ \\
\hline & $\begin{array}{l}\text { - Implementation of ERP system facilitates } \\
\text { CSC }\end{array}$ & & $\begin{array}{l}\text { - There is an efficient preventive } \\
\text { maintenance for CSC equipment }\end{array}$ \\
\hline & - Communication is complicated & & $\begin{array}{l}\text { - There are enough human resources in } \\
\text { maintenance department }\end{array}$ \\
\hline & - Implementation of Barcode in CSC system & & $\begin{array}{l}\text { - There are specialist technicians in } \\
\text { maintenance department }\end{array}$ \\
\hline & $\begin{array}{l}\text { - Use of GPS makes it easy to trace } \\
\text { transportation vehicles }\end{array}$ & & $\begin{array}{l}\text { - Having access to the right spares when } \\
\text { they are required }\end{array}$ \\
\hline \multirow{5}{*}{2} & - Ability to adapt new advanced & \multirow{5}{*}{15} & $\begin{array}{l}\text { - The warehouse saves products under } \\
\text { controllable temperature }\end{array}$ \\
\hline & & & - Warehouse spaces are enough \\
\hline & $\begin{array}{l}\text { - Continual improvement for technologies is } \\
\text { maintained }\end{array}$ & & $\begin{array}{l}\text { - There are non-occupied spaces in the } \\
\text { warehouse }\end{array}$ \\
\hline & $\begin{array}{l}\text { - A system exists to adapt to any new } \\
\text { advanced systems }\end{array}$ & & - Inventory height is high \\
\hline & $\begin{array}{l}\text { - Qualified experts and technicians operate } \\
\text { advanced technologies }\end{array}$ & & - Hazardous products stored separately \\
\hline \multirow{5}{*}{3} & $\begin{array}{l}\text { - Firm assigns the right employees in the } \\
\text { right position }\end{array}$ & \multirow{5}{*}{7} & - Investment required by CSC is high \\
\hline & $\begin{array}{l}\text { - All employees in the organization are well } \\
\text { qualified }\end{array}$ & & - Cost of waste in the organization is high \\
\hline & - There is a training program for employees & & $\begin{array}{l}\text { - Contraction cost with 3PL firm is higher } \\
\text { than local cold logistics }\end{array}$ \\
\hline & $\begin{array}{l}\text { - Firm does internal audits to CSC sector } \\
\text { employees }\end{array}$ & & - The logistics in CSC is costly \\
\hline & $\begin{array}{l}\text { - There is a motivating system for employee } \\
\text { toward improvement }\end{array}$ & & - The storage in CSC is costly \\
\hline
\end{tabular}


End of Table 6

\begin{tabular}{|c|c|c|c|}
\hline \multicolumn{4}{|c|}{ GSC measures } \\
\hline No. & Item & No. & Item \\
\hline \multirow{5}{*}{6} & $\begin{array}{l}\text { - Awareness about green CSC and its } \\
\text { benefits }\end{array}$ & \multirow{5}{*}{4} & $\begin{array}{l}\text { - Government issues industry friendly } \\
\text { policies toward green CSC }\end{array}$ \\
\hline & $\begin{array}{l}\text { - Customers are aware about green chain } \\
\text { and its benefits }\end{array}$ & & $\begin{array}{l}\text { - Government offers benefits to those } \\
\text { firms implementing green chain }\end{array}$ \\
\hline & $\begin{array}{l}\text { - Employees know when to consider the } \\
\text { situation as an incident }\end{array}$ & & $\begin{array}{l}\text { - Government facilitates the exportation of } \\
\text { green CSC products }\end{array}$ \\
\hline & $\begin{array}{l}\text { - Employees understand how to } \\
\text { communicate under emergency and what } \\
\text { critical external and internal resources are }\end{array}$ & & $\begin{array}{l}\text { - There is special reduction of taxes for } \\
\text { firms that apply green practices }\end{array}$ \\
\hline & $\begin{array}{l}\text { - Employees understand "Maximum } \\
\text { Tolerable Period of Disruption" }\end{array}$ & & $\begin{array}{l}\text { - Government facilitates green imports by } \\
\text { reducing custom taxes }\end{array}$ \\
\hline \multirow{6}{*}{5} & $\begin{array}{l}\text { - All fuel used in the green CSC are friendly } \\
\text { to the environment }\end{array}$ & \multirow{6}{*}{8} & \multirow{6}{*}{$\begin{array}{l}\text { - ISO } 14001 \text { increases green CSC } \\
\text { performance }\end{array}$} \\
\hline & $\begin{array}{l}\text { - Materials used in packaging process are } \\
\text { friendly to environment }\end{array}$ & & \\
\hline & - Firm support recycling & & \\
\hline & - Packs are reusable & & \\
\hline & $\begin{array}{l}\text { - Firm exploits or tends solar energy in cold } \\
\text { supply chain }\end{array}$ & & \\
\hline & $\begin{array}{l}\text { - Environmental friendly procedure of } \\
\text { hazardous solid waste disposal is followed }\end{array}$ & & \\
\hline \multicolumn{2}{|r|}{ ASC measures } & \multicolumn{2}{|r|}{ LSC measures } \\
\hline No. & Item & No & Item \\
\hline \multirow{4}{*}{12} & $\begin{array}{l}\text { - External (climatic, political, and } \\
\text { economical) conditions affect CSC }\end{array}$ & \multirow{7}{*}{9} & $\begin{array}{l}\text { - Use of } 5 \text { S and KAIZEN to minimize } \\
\text { waste in CSC }\end{array}$ \\
\hline & $\begin{array}{l}\text { - High responsiveness to non-predictable } \\
\text { changes }\end{array}$ & & $\begin{array}{l}\text { - Elimination of non-adding value steps in } \\
\text { transportation }\end{array}$ \\
\hline & $\begin{array}{l}\text { - Lead time between order and receive an } \\
\text { order is short }\end{array}$ & & - Suffer from over-production \\
\hline & $\begin{array}{l}\text { - High flexible respond to rapid change in } \\
\text { customer demand }\end{array}$ & & $\begin{array}{l}\text { - Delay in time in CSC is reduced or } \\
\text { eliminated }\end{array}$ \\
\hline \multirow{3}{*}{13} & \multirow{3}{*}{ - High level of customer satisfaction } & & $\begin{array}{l}\text { - Non-adding value processes are } \\
\text { eliminated or reduced }\end{array}$ \\
\hline & & & - A plan or strategy to minimize inventory \\
\hline & & & - High percentage of defects \\
\hline & RSC m & asure & \\
\hline No. & Item & No & Item \\
\hline \multirow{5}{*}{10} & $\begin{array}{l}\text { - There is a written plan for responding to } \\
\text { incidents }\end{array}$ & \multirow{5}{*}{11} & \multirow{5}{*}{$\begin{array}{l}\text { - An up-to-date contact detailed list of all } \\
\text { CS staff and their functions } \\
\text { - Suppliers' information is up-to-date } \\
\text { - An up-to-date location and time } \\
\text { information of transportation }\end{array}$} \\
\hline & - Contingency arrangements & & \\
\hline & $\begin{array}{l}\text { - Continuity planning of external critical } \\
\text { resources for emergency }\end{array}$ & & \\
\hline & $\begin{array}{l}\text { - Business gaps planning put in place for } \\
\text { improvement program }\end{array}$ & & \\
\hline & $\begin{array}{l}\text { - Accessibility to staff contact list even if } \\
\text { systems are inaccessible }\end{array}$ & & \\
\hline
\end{tabular}


Further analysis was conducted to assess the effectiveness of the implementation of each SCS capability and the results are then shown in Table 7. Table 8 displays the estimated mean and standard deviation of each measure for three sectors. Then, the following scale is used to assess cluster means: Very High: $>4.5$ to 5, High: $>4.00$ to 4.5 , Middle: $>3.5$ to 4.00 , low: $>3$ to 3.5 , and very low: $<3$, is used to assess respondent's average response about CSC measures. From Table 8, it is found that:

- For cluster II (low-middle dependency-driving power combination), the average (standard deviation) scores of government support system for GCSC are 1.92(0.73), 2.07(0.73), and 3.4 (0.82) for food, pharmaceutical, and 3PL industries, respectively. These average scores indicate very low government support for GCSC in food and pharmaceutical industry, whereas it is low in 3PL. Further, for cluster III (low-high), the respective firms' average (standard deviation) scores of ISO 14001 implementation are $4.5(0.2), 4.33(0.58)$, and 4.33 (0.58), which implies high impact of ISO 14001 implementation on GCSC.

- For cluster V (middle-middle power combination) measures; implementing green practices, preparedness to incidents and emergencies, maintenance management, and updating staff, suppliers, and transportation information, the averages of averages (standard deviation) scores for are 4.0 (0.77), $3.70(0.83)$, and $3.99(0.67)$, for food, pharmaceutical, and 3PL industries, respectively. The average values indicate middle average influence of cluster measures on CSC capability. For cluster VI (middle-high power combination) measures; IT implementation, Technology advancement adoption, and organizational awareness for green cold supply chain, the respective firms' averages of averages (standard deviation) scores are 3.83(1.39), 4.08 (1.36), and 4.24 (1.36), which indicate middle, high, and high effect of these cluster measures on CSC capability, respectively.

- For cluster VII (high-low power combination) measures; operational costs and customer satisfaction, the averages of averages (standard deviation) scores are 3.54(0.95), $2.88(0.8)$, and $3.22(0.79)$, for food, pharmaceutical, and 3PL industries, respectively. The average scores of the measures in cluster VII indicate middle, very low, and middle average influence of these cluster measures on CSC capability. The reason of such scores is the moderate mean values of operational costs. That is, the level of measures is not high enough to reduce the operating costs in the CSC.

- For cluster VIII (high-middle power combination) measures; lean practices and value addition, responsiveness to unpredictable demand, and cold warehousing and inventory management, the respective firms' averages of averages (standard deviation) scores are $3.68(0.66), 3.33(0.49)$, and $3.33(0.70)$. These values imply middle, low, and low average impact of these cluster measures on CSC capability. The contributors to such cluster level are the poor adoption of the lean and agile practices. Finally, in cluster XI (high-high power combination); human resources management, the respective firm averages (standard deviation) are 4.01 (0.66), 3.33 (0.49), and 3.33 (0.70). It is obvious that the pharmaceutical, and 3PL industries suffer low effectiveness in human resources management. 
Table 7. The estimated mean and standard deviation of each measure for three sectors

\begin{tabular}{|c|c|c|c|c|c|c|c|c|c|}
\hline \multirow{2}{*}{ Cluster } & \multirow{2}{*}{$\begin{array}{c}\text { Measure } \\
\text { No. }\end{array}$} & \multirow{2}{*}{ Practice } & \multirow{2}{*}{$\begin{array}{l}\text { ISM } \\
\text { Level }\end{array}$} & \multicolumn{2}{|c|}{ Food } & \multicolumn{2}{|c|}{ Pharmaceutical } & \multicolumn{2}{|c|}{$3 \mathrm{PL}$} \\
\hline & & & & Mean & Std. Dev. & Mean & Std. Dev. & Mean & Std. Dev. \\
\hline II & 5 & Green & 6 & 1.92 & 0.73 & 2.07 & 0.73 & 3.40 & 0.82 \\
\hline III & 8 & Green & 6 & 4.50 & 0.2 & 4.33 & 0.58 & 4.33 & 0.58 \\
\hline \multirow{4}{*}{$\mathrm{V}$} & 6 & Green & 3 & 3.67 & 0.94 & 3.56 & 0.85 & 4.22 & 0.71 \\
\hline & 10 & Resilient & 3 & 3.73 & 0.82 & 4.13 & 0.86 & 3.40 & 0.82 \\
\hline & 11 & Resilient & 4 & 4.33 & 0.65 & 3.42 & 0.71 & 4.22 & 0.71 \\
\hline & 14 & Cold & 4 & 4.27 & 0.68 & 3.67 & 0.89 & 4.11 & 0.44 \\
\hline \multicolumn{4}{|c|}{ Average } & 4 & 0.77 & 3.70 & 0.83 & 3.99 & 0.67 \\
\hline \multirow{3}{*}{ VI } & 1 & Cold & 5 & 3.83 & 0.91 & 4.50 & 0.82 & 4.33 & 0.82 \\
\hline & 2 & Cold & 5 & 4.50 & 0.76 & 4.33 & 0.76 & 4.00 & 0.91 \\
\hline & 4 & Green & 5 & 3.17 & 0.73 & 3.40 & 0.77 & 4.40 & 0.58 \\
\hline \multicolumn{4}{|c|}{ Average } & 3.83 & 1.39 & 4.08 & 1.36 & 4.24 & 1.36 \\
\hline & 7 & Cold & 1 & 2.78 & 0.91 & 2.06 & 0.58 & 2.78 & 0.41 \\
\hline VII & 13 & Agile & 1 & 4.30 & 0.60 & 3.70 & 0.40 & 3.67 & 0.26 \\
\hline \multicolumn{4}{|c|}{ Average } & 3.54 & 0.95 & 2.88 & 0.80 & 3.22 & 0.79 \\
\hline \multirow{3}{*}{ VIII } & 9 & Lean & 2 & 3.11 & 0.44 & 3.06 & 0.58 & 3.28 & 0.9 \\
\hline & 12 & Agile & 2 & 3.92 & 0.76 & 3.00 & 0.41 & 2.78 & 0.45 \\
\hline & 15 & Cold & 2 & 4.00 & 0.77 & 3.93 & 0.48 & 3.92 & 0.76 \\
\hline \multicolumn{4}{|c|}{ Average } & 3.68 & 0.66 & 3.33 & 0.49 & 3.33 & 0.70 \\
\hline IX & 3 & Cold & 2 & 3.58 & 0.89 & 4.20 & 0.68 & 4.27 & 0.68 \\
\hline \multicolumn{4}{|c|}{ Average } & 3.58 & 0.89 & 4.20 & 0.68 & 4.27 & 0.68 \\
\hline
\end{tabular}

Table 8. Analysis of SCS measures

\begin{tabular}{|c|c|c|c|c|c|c|}
\hline \multirow{2}{*}{ Capability } & \multicolumn{2}{|c|}{ Food } & \multicolumn{2}{c|}{ Pharmaceutical } & \multicolumn{2}{c|}{ 3PL } \\
\cline { 2 - 7 } & Mean & Std. Dev. & Mean & Std. Dev. & Mean & Std. Dev. \\
\hline Green & 3.32 & 0.64 & 3.34 & 0.83 & 4.09 & 0.79 \\
\hline Lean & 3.11 & 0.44 & 3.06 & 0.58 & 3.28 & 0.90 \\
\hline Resilient & 4.03 & 0.49 & 3.78 & 0.52 & 3.81 & 0.51 \\
\hline Agile & 4.11 & 0.71 & 3.35 & 0.45 & 3.23 & 0.34 \\
\hline Cold & 3.83 & 0.92 & 3.78 & 0.81 & 3.90 & 0.78 \\
\hline
\end{tabular}

From Table 8, it is found in food CSC that the application of green and lean practices is low, cold practices is middle, and resilient and agile practices is high. While in the pharmaceutical industry, the implementation levels of green, lean and agile practices are low, while the levels of both cold and resilient practices are middle. Finally, for the 3PL the application levels of lean and agile practices are low, while the levels of both cold and resilient practices are middle, but the adoption level of green practices is high. On the other hand, it is found that the 3PL high the highest level in the application of the green, lean, and cold practices. 
However, the food industry has the highest adoption level of resilient and agile practices. These findings assist top management of each firm in determining the needed improvements in green, lean, cold, resilient and agile practices and help in prioritizing the appropriate actions required to enhance the capability of their CSC.

\section{Conclusions}

The contribution of this research is mainly to develop a structural model to depict the relationships between the measures of lean, green, resilient, and agile practices in cold supply chain and then categorize them into hierarchal levels, and finally identify the important measures of high driving power and high dependency power on which top management should focus in order to enhance the capability of CSC. Results showed that the developed ISM for CSC includes six hierarchal levels; in which the operational costs and customer satisfaction were the highly dependent measures, whereas ISO 14001 implementation and government support system for green cold supply chain were the highly driving. To validate the model, three CSC firms from food sector, pharmaceutical, and Third Party logistics (3PL) were assessed to identify the impact of the lean, green, resilient, agile and cold practices on CSC capability. It is found that the developed ISM model effectively depicted the relationships between the measures of lean, green, resilient, and agility in cold supply chain, which provides significant information to decision makers and planning engineers on how those measures are interrelated and provides their impacts be identifying those with high driving power and dependent power. In practice, the results of this research supports top management by finding the high driving power lean, green, resilient, agile, and cold measures, which need to be considered on a priority basis as well as determining these measures emerging with high dependence which contribute to enhancing the performance of the CSC. This will save costly improvement time and efforts and result in achieving effective CSC.

\section{Author contributions}

Abbas Al-Refaie and Mohammad AL-Tahat conceived the study and were responsible for the structural modelling, data collection and analysis, and results interpretation. Natalija Lepkova was responsible for review of the presented literature, data analysis, and models validation on real industrial application in the article.

\section{Disclosure statement}

Authors do not have any competing financial, professional, or personal interests from other parties. The authors declare no conflict of interest. 


\section{References}

Azevedo, S., Carvalho, H., \& Cruz-Machado, V. (2016). LARG index. Benchmarking: An International Journal, 23(6), 1472-1499. https://doi.org/10.1108/BIJ-07-2014-0072

Blanchard, D. (2007). Supply chain management best practices. John Wiley \& sons, Inc.

Balaji, M., Velmurugan, V., Prapa, M., \& Mythily, V. (2016). A fuzzy approach for modeling and design of agile supply chains using interpretive structural modeling. Jordan Journal of Mechanical and Industrial Engineering, 10(1), 67-74.

Behzadi, G., O’Sullivan, M. J., Olsen, T. L., Scrimgeour, F., \& Zhang, A. (2017). Robust and resilient strategies for managing supply disruptions in an agribusiness supply chain. International Journal of Production Economics, 191, 207-220. https://doi.org/10.1016/j.ijpe.2017.06.018

Bicocchi, N., Cabri, G., Mandreoli, F., \& Mecella, M. (2019). Dynamic digital factories for agile supply chains: An architectural approach. Journal of Industrial Information Integration, 15, 111-121. https://doi.org/10.1016/j.jii.2019.02.001

Bogataj, M., Bogataj, L., \& Vodopivec, R. (2005). Stability of perishable goods in cold logistic chains. International Journal of Production Economics, 93-94(8), 345-356. https://doi.org/10.1016/j.ijpe.2004.06.032

Bogataj, D., Bogataj, M., \& Hudoklin, D. (2017). Mitigating risks of perishable products in the cyberphysical systems based on the extended MRP model. International Journal of Production Economics, 193, 51-62. https://doi.org/10.1016/j.ijpe.2017.06.028

Cabral, I., Grilo, A., \& Cruz-Machado, V. (2015). A decision-making model for Lean, Agile, Resilient and Green supply chain management. International Journal of Production Research, 50(17), 4830-4845. https://doi.org/10.1080/00207543.2012.657970

Carvalho, H., Duarte, S., \& Cruz-Machado, V. (2011). Lean, agile, resilient and green: divergencies and synergies. International Journal of Lean Six Sigma, 2(2), 151-179.

https://doi.org/10.1108/20401461111135037

Carvalho, H., Maleki, M., \& Cruz-Machado, V. (2012). The links between supply chain disturbances and resilience strategies. International Journal of Agile Systems and Management, 5(3), 203-234. https://doi.org/10.1504/IJASM.2012.047653

Chien, M. K., \& Shih, L. H. (2007). Relationship between Management Practice and Organization Performance under European union directives such as ROHS, a case study on the Electrical and Electronics industry in Taiwan. African journal of Environmental Science and Technology, 1(3), 37-48.

Ehsan, K., Tayyebeh, A., Ahmad, E., \& Tamošaitiene, J. (2016). The effect of green supply chain management practices on environmental performance and competitive advantage: a case study of the cement industry. Technological and Economic Development of Economy, 22(2), 293-308. https://doi.org/10.3846/20294913.2015.1065521

Espadinha-Cruz, P., Grilo, A., \& Cruz-Machado, V. (2012). Fuzzy evaluation model to assess interoperability in LARG Supply Chains. In 9th International Conference on Fuzzy Systems and Knowledge Discovery, (pp. 75-79). Sichuan. https://doi.org/10.1109/FSKD.2012.6234169

Gao, J., Xiao, Z., Wei, H., \& Zhou, G. (2018). Active or passive? Sustainable manufacturing in the directchannel green supply chain: A perspective of two types of green product designs. Transportation Research Part D, 65, 332-354. https://doi.org/10.1016/j.trd.2018.09.007

Govindan, K., Azevedo, S. G., Carvalho, H., \& Cruz-Machado, V. (2015). Lean, green and influence on supply chain performance: interpretive structural modeling approach. International Journal of Environmental Science and Technology, 12, 15-34. https://doi.org/10.1007/s13762-013-0409-7

Hsu, C. W., \& Hu, A. H. (2008). Green supply chain management in the electronic industry. International Journal of Science and Technology, 5(2), 205-216. https://doi.org/10.1007/BF03326014 
Holweg, M. (2007). The genealogy of lean production. Journal of Operation Management, 25(2), 420437. https://doi.org/10.1016/j.jom.2006.04.001

Iakovou, E., Vlachos, D., \& Xanthopoulos, A. (2007). An analytical methodological framework for the optimal design of resilient supply chains. International Journal of Logistics Economics and Globalisation, 1(1), 1-20. https://doi.org/10.1504/IJLEG.2007.014498

Khidir, T., Tayeb, E., Zailani, S., \& Jayaraman, K. (2010). The examination on the drivers for green purchasing adoption among EMS 14001 certified companies in Malaysia. Journal of Manufacturing Technology Management, 21(2), 206-225. https://doi.org/10.1108/17410381011014378

Kumar, N., Kumar, S., Haleem, A., \& Gahlot, P. (2013). Implementing lean manufacturing system: ISM approach. Journal of Industrial Engineering and Management, 6(4), 996-1012. https://doi.org/10.3926/jiem.508

Luthra, S., Kumar, V., Kumar, S., \&Haleem, A. (2011). Barriers to implement green supply chain management in automobile industry using interpretive structural modeling technique-An Indian perspective. Journal of Industrial Engineering and Management, 4(2), 231-257. https://doi.org/10.3926/jiem.2011.v4n2.p231-257

Martínez-Jurado, P. J., \& Moyano-Fuentes, J. (2014). Lean management, supply chain management and sustainability: A literature review. Journal of Cleaner Production, 85, 134-150. https://doi.org/10.1016/j.jclepro.2013.09.042

Mejjaouli, S., \& Babiceanu, R. F. (2018). Cold supply chain logistics: System optimization for real-time rerouting transportation solutions. Computers in Industry, 95, 68-80. https://doi.org/10.1016/j.compind.2017.12.006

Paauwe, J. (2009). HRM and performance: Achievement, methodological issues and prospects. Journal of Management Studies, 46(1). https://doi.org/10.1111/j.1467-6486.2008.00809.x

Raut, R. D., Gardas, B. B., Narwane, V. S., \& Narkhede, B. E. (2019). Improvement in the food losses in fruits and vegetable supply chain-a perspective of cold third-party logistics approach. Operations Research Perspectives, 6, 100-117. https://doi.org/10.1016/j.orp.2019.100117

Ruiz-Benitez, R., López, C., \& Real, J. C. (2017). Environmental benefits of lean, green and resilient supply chain management: The case of the aerospace sector. Journal of Cleaner Production, 167, 850-862. https://doi.org/10.1016/j.jclepro.2017.07.201

Sage, A. (1977). Interpretive structural modeling: Methodology for large scale systems. McGraw-Hill.

Svensson, G. (2010). Teleological approaches in supply chain management: illustrations. Supply Chain Management: An International Journal, 15(1), 16-20. https://doi.org/10.1108/13598541011018094

Taghikhah, F., Voinov, A., \& Shukla, N. (2019). Extending the supply chain to address sustainability. Journal of Cleaner Production, 229, 652-666. https://doi.org/10.1016/j.jclepro.2019.05.051

Tang, C. (2006). Robust strategies for mitigating supply chain disruptions. International Journal of Logistics-Research and Applications, 9(1), 33-45. https://doi.org/10.1080/13675560500405584

Taylor, D. (2006). Global cases in logistics and supply chain management. Thompson, South Western, USA.

Zhu, Q., Sarkis, J., \& Lai, K. (2008). Green supply chain management implications for "closing the loop". Transport Research Part E, 44(1), 1-18. https://doi.org/10.1016/j.tre.2006.06.003

Zobel, C. (2011). Representing perceived tradeoffs in defining disaster resilience. Decision Support Systems, 50(2), 394-403. https://doi.org/10.1016/j.dss.2010.10.001 